ISSN 2078-6441. Вісник Львівського університету. Серія географічна. 2013. Випуск 42. С. 221-232. Visnyk of the Lviv University. Series Geography. 2013. Issue 42. P. 221-232.

$502.131 .1(262.5+262.54)$

\author{
нн удрик, олодимир ортной \\ ерченський держ вний морський технологічний університет, \\ вул. рджсонікідзе, 82, 98300, м. ерч, рим, кр їн, \\ e-mail: inna_kudrik@mail.ru
}

озглянуто структуру й особливості рейдового перев нт ження в ерченській протоці. ро н лізов но мех нізми впливу н н вколишне середовище т екологічну безпеку портових комплексів н прикл ді зовнішніх перев нт жув льних рейдів, стоянки № 450, № 471

і перев нт жув льного комплексу “ м нський”, стоянки № 451 (порт $\quad$ вк 3). ведено н ліз впливу перев нт жув льних робіт т експлу т ції судового уст ткув ння н н вколишне середовище. изн чено низку чинників, з допомогою ур хув ння яких можн вдоскон лити методику оцінки екологічного ст ну морського середовищ .

лючові слов : екологічн безпек, морегоспод рський комплекс, рейдові опер ції, з бруднення н вколишнього середовищ .

орське середовище - в жлив економічн л нк в з безпеченні ст лого розвитку римського регіону. лючовими елемент ми морегоспод рської г лузі регіону $\epsilon$ морські порти і системи рейдових перев нт жув льних комплексів, н яких 3 мик ється діяльність пр ктично всіх інших підприємств і орг ніз цій, що н леж ть до комплексу берег-море. узбережжі орного $\mathrm{T}$ зовського морів розт шов но 19 морських портів, у тому числі торгових. еякі з них пров дять свою діяльність у ерченській протоці. е економічно вигідно, одн к нег тивно вплив є н екологічне ст новище кв торії протоки. ерев нт жув льні опер ції виконують у режимі відкритого рейду, потім 3 допомогою берегових тр нспортно-перев нт жув льних 3 собів в нт жі пост ч ють у цільові портові комплекси. ід відкритим рейдом розуміють кв торію, прид тну для стоянки суден н якорі тільки з певних умов і не з хищену від впливу вітру і хвиль. еред в ння в нт жів відбув ється н судн х, ошв ртов них л гом 3 схемою, пок 3 ною н рис. 1 . ерченській протоці кр їн відпр цьовує якірні стоянки № 450, 452, 453, 471 ( ерченський морський торговий порт ( ) ) (див. рис. 2), т кож рейдовий перев нт жув льний комплекс “" м нський” і рейдову стоянку № 451, що входять до сфери відповід льності морської дміністр ції портів емрюк і вк з ( осія) (див. рис. 3).

рейді в укр їнській ч стині ерченської протоки щорічно переробляють пон д 17 млн т в нт жів. $95 \%$ це російські в нт жі, які н дходять 3 портів олги, ону т спію судн ми типу рік -море, потім їх перев нт жують н великотонн жні судн . сновн номенкл тур - сірк , н фтопродукти, зерно, вугілля, цукор-сирець.

нт жні опер ції н зовнішньому перев нт жув льному рейді відбув ються н якірній стоянці № 471. тоянк відкрит відповідно до рішення оловної держ вної інспекції кр їни з безпеки суднопл вств 2000 р., 3 н к зом іністерств тр нспор-

(C) удрик ., ортной ., 2013 
ту кр їни дозволено перев нт ження в нт жів н рейді. тоянк $€$ зоною митного контролю ерченського морського торгового порту і призн чен для в нт жних опер цій, м є 46 якірних місць.

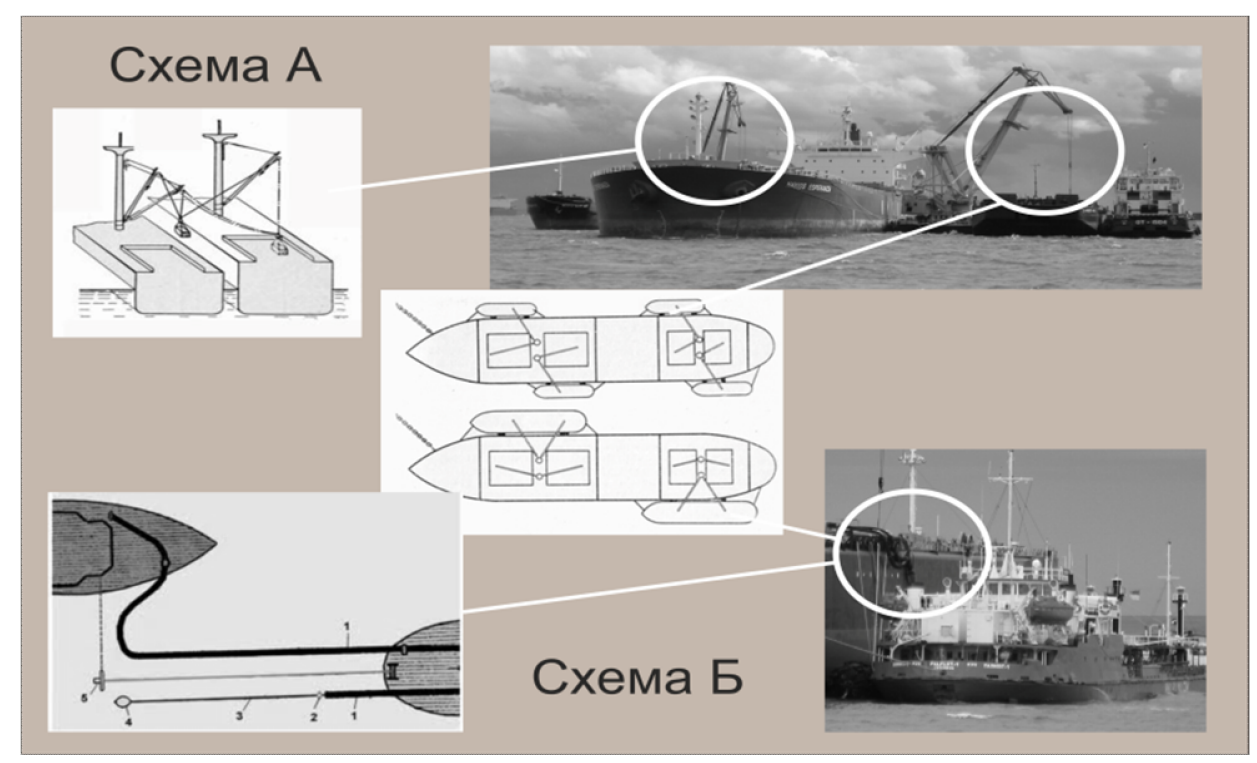

ис. 1. г льн схем перев нт жув льних рейдових опер цій:

- метод перев нт ження твердих і сипких в нт жів; - метод перев нт ження рідких в нт жів [6].

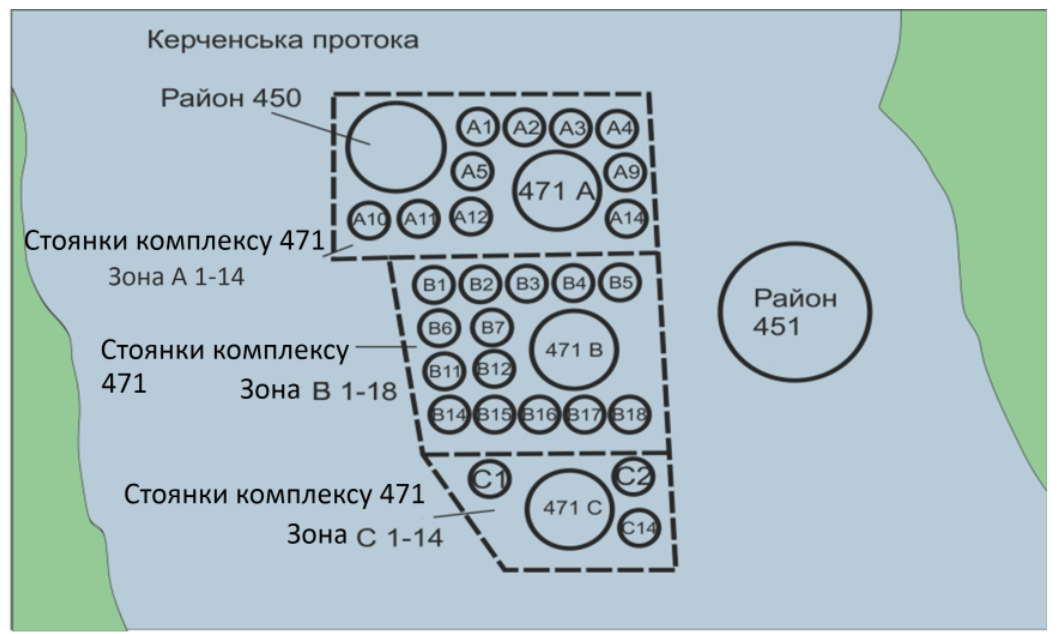

ис. 2. хем розт шув ння комплексів рейдового перев нт ження у ерченській протоці. ейдов стоянк № 471, ерченський морський торговий порт. йон - вугілля, кокс; $p$ йон - цукор-сирець; $p$ йон - 12 -ільменіт; 18 -добриво; $p$ йон - 4-з лізорудний концентр т; 6-кукурудз , гірчиця, соя; 8-10-сірк ; 12 -зернові. ейдов стоянк № 451 (порт вк з) перев нт ження м зуту, н фти, н сипних і н в лочних в нт жів. 


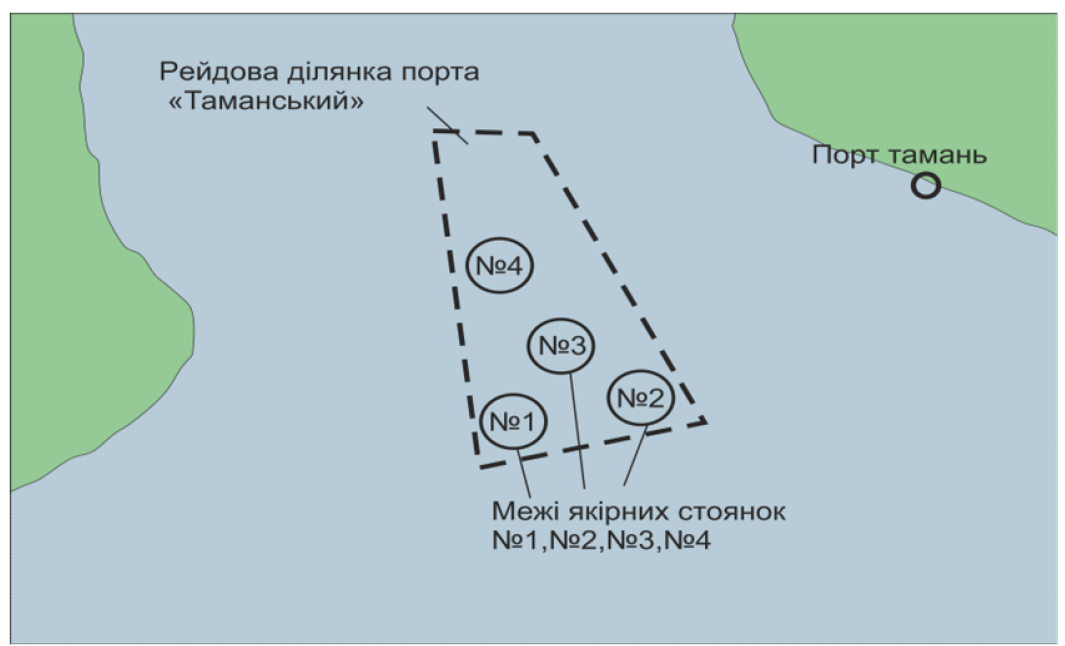

ис. 3. ісце розміщення якірних стоянок н рейдовій ділянці “ м нський” (порт вк з), перев жн номенкл тур - н фтопродукти, м зут.

ейдов стоянк призн чен для відстою декількох т нкерів-н копичув чів (російськ сторон - 4 шт.). одотонн жність - 100 тис. т для перев нт ження н фтопродуктів, головно, м зуту м рки -100 з схемою борт-борт. нкери повинні виконув ти функції пл вучих термін лів. о суден-н копичув чів т нкер ми типу рік -море передб чено дост вляти м зут по зовському морю. рієнтовн кількість 3 ходження суден н рейдову стоянку в н віг цію: 200 т нкерів-перевізників дедвейтом 5 тис. т і 25 т нкерів-тр нспортув льників дедвейтом від 20 до 100 тис. т. я інформ ція ч сто супроводжується з певненнями, що "нег тивний вплив буде незн чним", “шкод н вколишньому середовищу є помірною” тощо. дн к м тері ли оцінки впливу н н вколишнє середовище ( ) у цьому бсолютно не переконують. досвід к т строф у ерченській протоці з свідчує, н скільки ці висновки непр вдиві.

період проведення моніторингу в р йоні рейдових перев нт жень н в нт жнорозв нт жув льних комплекс х укр їнської сторони з 11 місяців 2011 р. перероблено 1623742,3 т н в люв льних в нт жів у сумі порівняно із з г льною кількістю 1593042,0 т у 2009 р. (див. т бл. 1).

ейдові перев нт жув льні комплекси ( ) у ерченській протоці т кож призн чені для перев нт ження н фти, як укр їнською, т к і російською стороною $з$ схемою т нкери-перевізники н т нкери-тр нспортув льники через т нкер-н копичув ч (див. рис. 4).

російського боку приблизний обсяг перев нт жень н фтопродуктів можн оцінити н прикл ді рейдового перев нт жув льного комплексу “" м нський”, орг нізов ного н рейдових перев нт жув льних місцях кв торії порту вк з у ерченській протоці. ут м ньн фтог з провів опер ції об’ємом 1,415 млн т у період з липня до грудня 2012 р.

квітні 2013 р. м ньн фтог $з$ поч в перев нт ження м зуту. рік комп нія пл нує відв нт жув ти 3,5 млн т продукту, отже, пл нов ний обсяг перев нт ження продуктів ст новитиме 10,5 млн т з рік, у тому числі 1,0 млн т зрідженого вуглеводневого г зу. 
блиця 1

ількість перероблених в нт жів стоянкою № 471 з січень-листоп д 2011 р., т [3, 4]

\begin{tabular}{|r|c|c|c|c|c|c|}
\hline \multirow{2}{*}{ ісяць } & \multicolumn{5}{|c|}{ нт ж } & \multirow{2}{*}{ сього } \\
\cline { 2 - 7 } & сірк & зернові & з лізорудний концентр т & вугілля & кокс & \\
\hline ічень & - & - & 109015,4 & - & - & 109015,4 \\
\hline ютий & - & - & 94880,7 & - & - & 94880,7 \\
\hline ерезень & - & - & 180453,6 & - & - & 180453,6 \\
\hline вітень & 41896,02 & - & 99931,4 & - & - & 141827,42 \\
\hline р вень & 109384,9 & - & 73458,2 & - & - & 182843,1 \\
\hline ервень & 57749,3 & 32769,9 & 41722 & 5927,4 & - & 138168,6 \\
\hline ипень & - & - & 164159 & 73442,1 & - & 237601,1 \\
\hline ерпень & - & 38194,7 & 207005,5 & 95452,7 & - & 340652,9 \\
\hline ересень & - & - & 107237 & 10833 & - & 118070 \\
\hline овтень & - & - & 101,6 & - & - & 101,6 \\
\hline истоп д & 19123 & - & 19823,6 & 35000 & 6181,3 & 80127,9 \\
\hline & 228153,22 & 70964,6 & 1097788 & 220655,2 & 6181,3 & 1623742,3 \\
\hline
\end{tabular}

ому великотонн жні т нкери, з звич й, в нт жопідйомністю близько і пон д 100 тис. т очікують у південній ч стині ерченської протоки, як не 3 мерз є, бо в p йоні рейдової стоянки. о них ч сто і регулярно підходять т нкери типу рік -море 3 остов й зов , кожен $з$ яких везе від 3 до 6 тис. т н фти. і порівняно м ленькі “річкові” т нкери ст ють до суперт нкерів-н копичув чів (див. рис. 4) л гом, тобто борт до борту, і перек чують у їхні резерву ри привезену н фту (див. рис. 5). егко визн чити, що для повного з в нт ження т нкер -н копичув ч потрібно приблизно 20-30-40 т ких, менших т нкерів-тр нспортув льників.

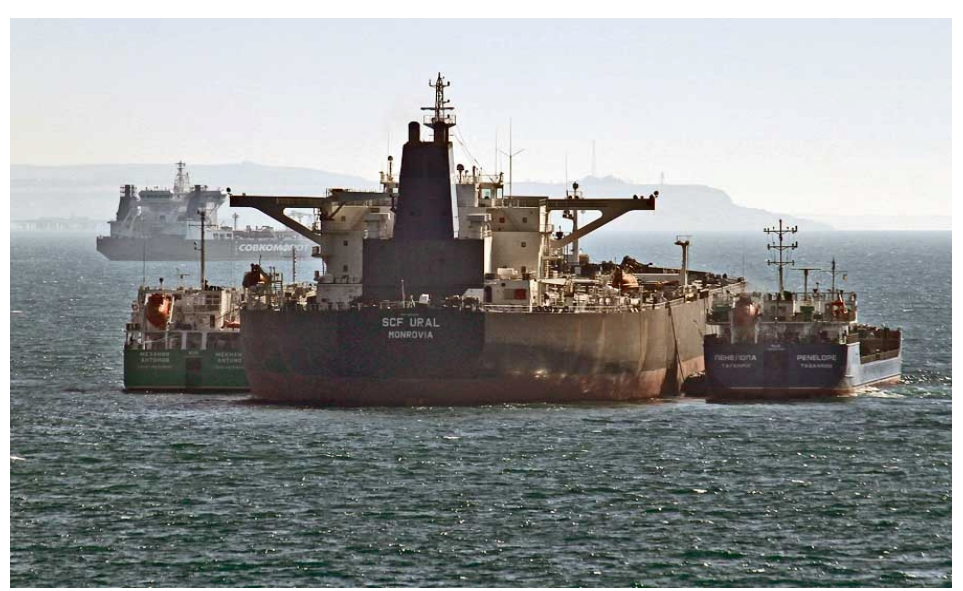

ис. 4. еликотонн жний т нкер-н копичув ч у ерченській протоці. 


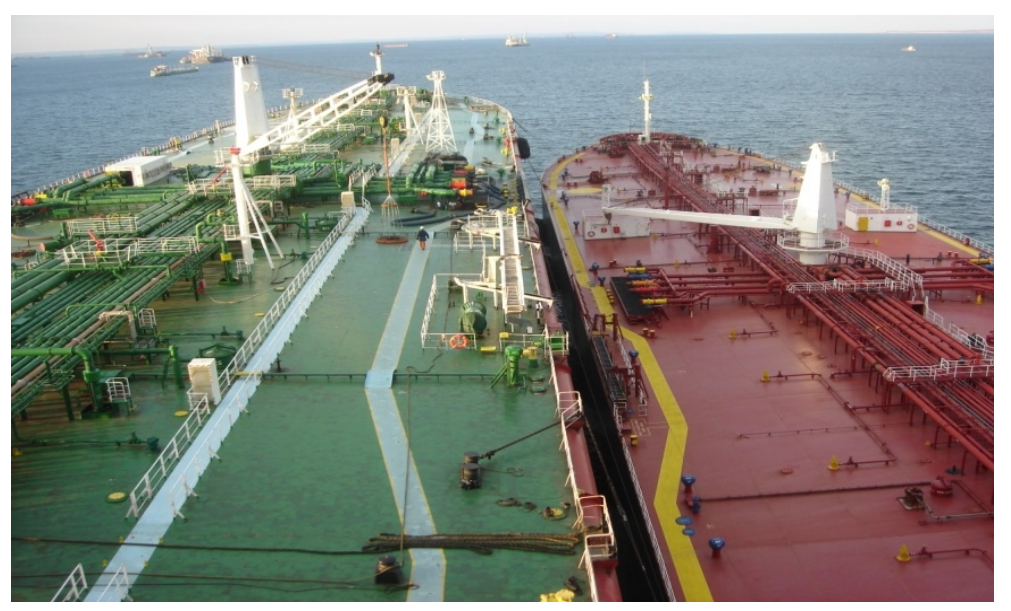

ис. 5. ерев нт ження н ливних в нт жів н рейді ерченської протоки з схемою борт до борту л гом $з$ т нкер -тр нспортув льник н т нкер-н копичув ч [5].

н слідок дослідження, проведеного з період з 21 червня 2011 по 25 тр вня 2012 р., виявлено групу з п'яти великих т нкерів-н копичув чів, які перебув ли в ерченській протоці б г то місяців поспіль. прикл д, т нкер “Aleksey Kosygin” тонн жністю 163545 т прибув 4 лютого 2011 p. і стоїть у протоці досі. погляду екології р йон рейдових опер цій нег тивно вплив є н тмосферне повітря т водні біоресурси р йону. с мперед це стосується донних біоценозів ун слідок прямого впливу н нього під ч с ст влення і зняття суден з якорів, днопоглиблюв льних робіт, д мпінгу. о стосується прямого т непрямого впливу, то в р йоні відбув ється підвищення вмісту з вислих речовин у воді, що т кож нег тивно позн ч ється н біоті і бентосі р йону. н слідок постійної н явності в р йоні суден т інтенсивного ведення в нт жних опер цій у період н віг ції виник є чинник з непокоєння, який може порушити трофічні відношення в р йоні, нег тивно позн читися н використ нні риб ми р йону як нерестових і н гульних площ. оже відбув тися нег тивний вплив н мігр ційні процеси риб з орного моря в зовське і н з д.

кремо з зн чимо про вплив н морські екосистеми берегових тр нспортноперев нт жув льних комплексів, які $є$ л нкою 3 г льної схеми тр нспортув ння в нт жів від рейдових комплексів до берегових портових сховищ. озміщення технічних комплексів і скупчення сипучих в нт жів у безпосередній близькості до берегової зони призводить до розвитку зсувних, ерозійних процесів т з бруднення прибережної кв торії вн слідок просип ння й утворення пилової суспензії (під ч с перев нт ження руди, мінер льних добрив, к м'яного вугілля, мет лобрухту тощо) (див. рис. 6). орські порти т кож $є$ одним 3 основних джерел н дходження в морське середовище недоочищених стічних вод, зливових стоків [5].

сукупності все це нег тивно позн ч ється н продуктивності водойми. дн к точні д ні потребують трив лих досліджень.

підст ві ж уже проведених спостережень можн зробити висновок щодо екологічного впливу т кого трив лого перебув ння великої кількості великотонн жних суден н рейдовій стоянці. 


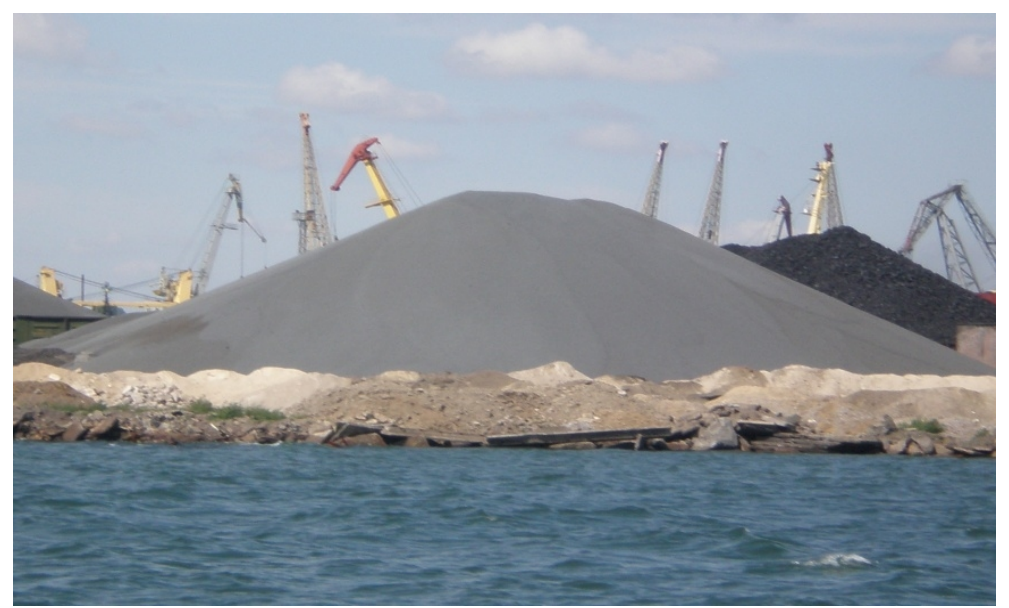

ис. 6. йд нчик для зберіг ння сипких в нт жів з відсутністю з хисних технічних споруд. фото чітко відобр жений ст н берегової зони.

погляду впливу н тмосферне повітря основними джерел ми з бруднення є:

- силові енергетичні уст новки (головні і допоміжні дизельні двигуни, дизельгенер тори, п рові котли) т нкерів-н копичув чів, т нкерів-пост ч льників, т нкерівтр нспортув льників, буксирів;

- $\quad$ н фтопродукти під ч с їх прийм ння, зберіг ння т відв нт ження;

- $\quad$ сипкі в нт жі під ч с їх прийм ння т перев нт ження.

ід ч с роботи головних і допоміжних силових уст новок в тмосферне повітря виділяються т кі речовини:

- з зоту діоксид;

- $\quad$ зоту оксид;

- $\quad$ с ж ;

- $\quad$ сірки діоксид;

- $\quad$ вуглецю оксид;

- бенз( )пірен;

- вуглеводні гр ничні 12- 19.

мності (т нки) для зберіг ння н фтопродуктів усіх суден, з діяних у технологічному процесі прийм ння, зберіг ння, відв нт ження н фтопродуктів, є джерел ми виділення в тмосферне повітря т ких з бруднюв льних речовин (з д ними моніторингових досліджень івден , м тері л ми конс лтингової фірми “ ”):

- сірководень;

- вуглеводні гр ничні 12- 19;

- бензол;

- ксилол;

- толуол.

н слідок трив лої стоянки н копичується великий обсяг лляльних вод, що містять н фтопродукти і в жкі мет ли (підтік ння дейдвудної втулки, протік ння двигун і систем под чі м стил , з чистк т нків), зі зношенням судн ці п р метри збільшуються. ур хув нням розмірів і кількості суден н рейді обсяги побутових відходів, 
лляльних і фек льних вод можуть досяг ти десятків і сотень тонн з місяць, б г то суден не $з$ ходять у порт протягом трив лого ч су, торговий порт не м є дост тньої кількості технічних з собів для збир ння з суден т кої кількості відходів. тже, відбув ються періодичні нес нкціонов ні скиди у морське середовище (рис. 7), що є порушенням принципів екологічної безпеки, т кож норм міжн родного пр вового з конод вств щодо умов для дозволеного скид ння відходів і стічних вод; ця територія н лежить до к тегорії особливого р йону ( 73.78).

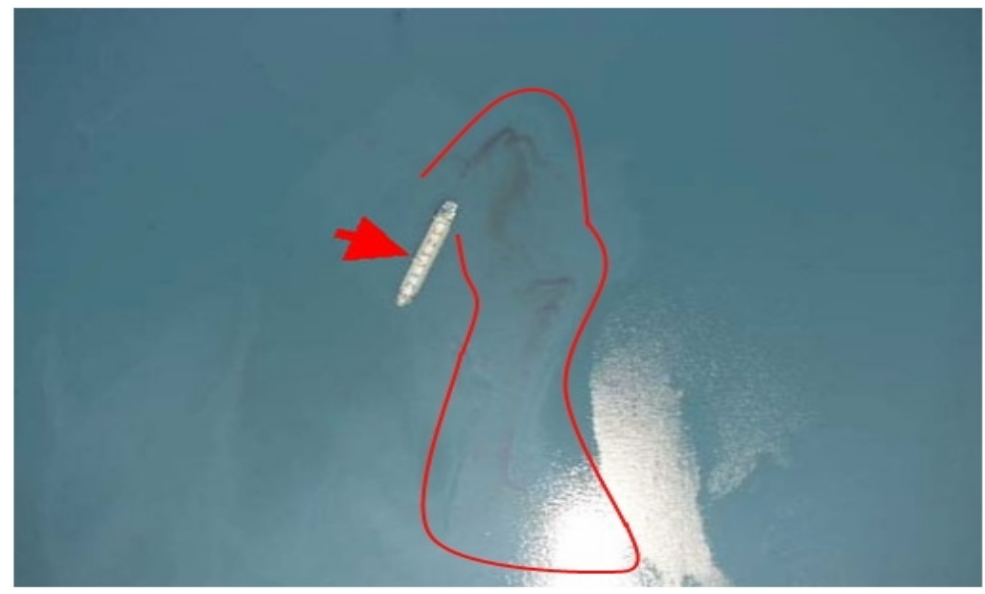

ис. 7. кид ння лляльних вод в кв торію ерченської протоки.

ході рейдових опер цій у ерченській протоці ктивно використовують судн типу “ олго- лт”, з чим пов'яз н низк екологічних проблем. удн цього типу поч ли експлу тув ти пон д 30 років тому. них для економії використовують в жке п льне - п льне погіршеної якості (флотські м зути - зміш ння з лишкових н фтопродуктів (м зут, гудрон, в жкі г зойлі вторинних процесів) і дизельних фр кцій). рім інших несприятливих пок зників якості обв жненого і в жкого п льного, - підвищений вміст у них сірки (у 35 р зів більше ст нд ртного пок зник ). е озн ч є, що в скл ді відпр цьов них г зів зн чно збільшений вміст сірч ного і сірчистого нгідриду, тобто потенційних кислотовмісних продуктів, вплив яких різко нег тивно позн ч ється н н вколишньому середовищі. іншого боку, в жке п льне в суч сних дизелях без спеці льно вжитих з ходів згор є не повністю, отже, димність відпр цьов них г зів зрост є в кільк р зів порівняно з роботою дизелів н ст нд ртному дизельному п льному. фотогр фії (див. рис. 8), зробленій у ерченській протоці, чітко видно технічний ст н в нт жного судн, яке перебув є н відст ні від берег пон д 20 миль.

зн чимо, що проток н лежить до к тегорії морських особливих р йонів, щодо яких ст влять особливі вимоги до методів з побіг ння з брудненню моря (судн , перебув ючи в особливому р йоні, зберіг ють н борту всі н фтові з лишки, брудний 6 л ст і промив льну воду, потім зд ють їх тільки в портові прийомні пристрої), для г р нтув ння безпеки морепл в ння й екологічного бл гополуччя $\mathrm{p}$ йону. дн к територія зовнішнього перев нт жув льного рейду ерченського морського торгового порту є зоною з критого кордону, що зн чно ускл днює бо унеможливлює контроль 
3 дотрим нням норм морського пр в т г р нтув ння екологічної безпеки ерченської протоки і орного моря з г лом.

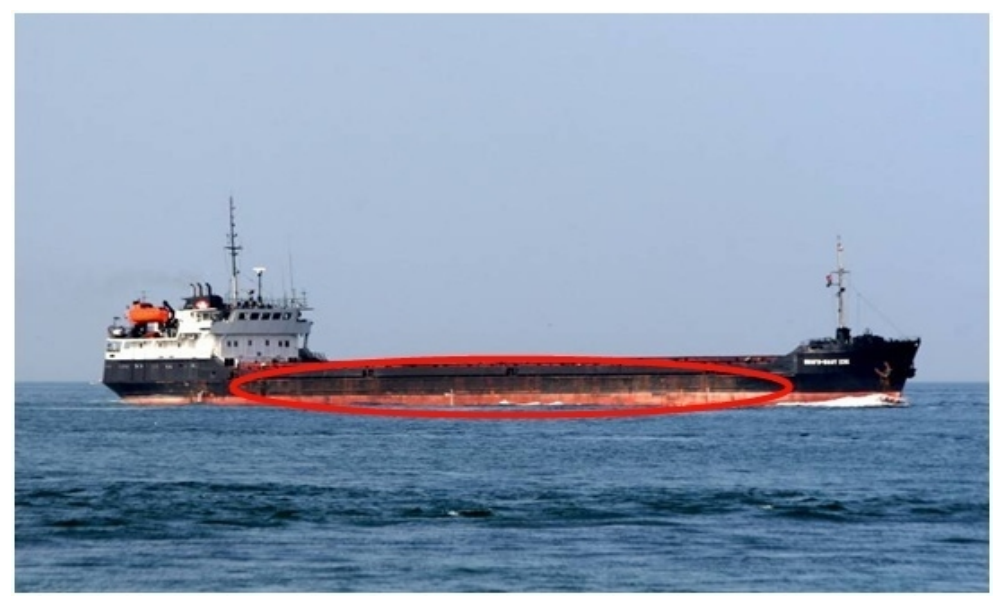

ис. 8. ехнічний ст н корпусу судн “ олго- лт”.

йон рейдового перев нт жув льного комплексу охоплює стоянки як укр їнської, т к і російської сторін і розміщений у небезпечній близькості до н селених пунктів. елище олн ( осія) розт шов не н відст ні всього 6 км від пл нов ної стоянки, 3 5 км від цього комплексу і укр їнський н селений пункт бережне.

орне море - одне з н йбільше з бруднених у світі, головно, через скид ння промислових вод т н фторозливів, ун слідок зн чного обсягу перевезень н фтових в нт жів. огляду н це екологічн ситу ція в орному морі і, зокрем , н шельфі пр ктично ст л критичною. кл дн екологічн ситу ція і в ерченській протоці. ерченськ проток - зон підвищеного нтропогенного н в нт ження, і для його кв торії х р ктерні підвищені концентр ції н фтопродуктів, що пов'яз но з інтенсифік цією суднопл вств, т кож неконтрольов ними рейдовими перев нт женнями н фтопродуктів російської т укр їнської сторін.

ерелік визн чених п р метрів ст ну екосистеми, зн чення яких нормують у морських вод х, охоплює пок зники, змін яких прямо бо опосередков но може чинити н йбільший вплив н морську екосистему.

ерелік з бруднюв льних речовин морського середовищ т їхні гр ничнодопустимі концентр ції ( ) н ведені в т бл. 2.

о основних екологічних проблем досліджув ного р йону можн 3 числити т кі:

- високе і постійне скупчення суден н порівняно невеликій площі, що зумовлює низку з зн чених вище проблем з н копиченням і скид нням різних видів виробничих відходів, що знижує зд тність морського середовищ до с мовідновлення і с морегулюв ння. ідсутність об'єктивної системи контролю з скид нням відходів, т кож технічних з собів зі збир ння великого обсягу н копичених відходів. ідр хов но, що н момент в рії 2007 р. н рейді перебув ло 167 суден. едоскон лість технічних і технологічних вирішень $з$ попередження з бруднення морського середовищ н фтою під ч с проведення опер цій з н фтою. евикон ння в необхідному обсязі комплексу 
природоохоронних з ходів у ході ведення діяльності, пов'яз ної з проведенням опер цій 3 н фтою у прибережній морській зоні. ідсутність ефективної системи охорони прибережних морських екосистем, що з безпечують систем тичну оцінку екологічної ситу ції, визн чення пріоритетних проблем, розробку т ре ліз цію комплексу природоохоронних з ходів щодо з побіг ння з брудненню морського середовищ н фтою й опер тивної ліквід ції н слідків н фтового з бруднення;

- втр т в нт жу як джерело з бруднення тмосфери т гідросфери. більшення обсягу перев нт ження сипких і рідких в нт жів у середньому н 30700 т з рік; 3 різними оцінк ми, природні шляхові втр ти під ч с тр нспортув ння і перев нт ження н фтопродуктів ст новлять $2 \%$, тобто кількісні втр ти ст новитимуть 0,4-0,6\% (кількісні втр ти н фтопродуктів спричинені нез довільними конструкціями і технічним ст ном обл дн ння т рм тури н тр нспорті, н фтоб з х і, , т кож недб лістю окремих співробітників). судн х, н фтоб з х, трубопровод х є сотні сполук, які ст ють джерел ми втр т. ведені зн чення не вр ховують погодних умов і технічного ст ну суден, що виконують перевезення. есприятливі погодні умови т нез довільний ст н технічних з собів сприяють збільшенню втр т у кільк $\mathrm{p}$ зів. відомості, згідно з якими, втр т н ливного в нт жу в штормову погоду досягл $11 \%$. ля сипких в нт жів цей пок зник ст новить $1,3 \%$ без ур хув ння погодних умов. огляду н ці д ні у н вколишне природне середовище щорічно може н дходити 20000 т різних хімічних речовин.

блищя 2

ерелік з бруднюв льних речовин, які контролюють у ерченській протоці [3]

\begin{tabular}{|c|c|c|}
\hline ок ЗнИк & $\begin{array}{c}\text { диниці } \\
\text { вимірюв ння }\end{array}$ & \\
\hline озчинений кисень & мг/дм ${ }^{3}$ & е менше 4,0 \\
\hline вислі речовини & мг/дм ${ }^{3}$ & $\begin{array}{c}\text { онові зн чення р йону } \\
\text { водокористув ння }\end{array}$ \\
\hline олоність & $\mathrm{X}$ & $12-18$ \\
\hline ульф ти & г/дм ${ }^{3}$ & 3,5 \\
\hline лор-іон & г/дм ${ }^{3}$ & 11,9 \\
\hline моній сольовий & мг дм ${ }^{3}$ & 0,5 \\
\hline ітр ти & мг/дм ${ }^{3}$ & 40,0 \\
\hline ітрити & мг/дм ${ }^{3}$ & 0,08 \\
\hline фтопродукти & мг/дм ${ }^{3}$ & 0,05 \\
\hline 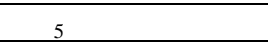 & мГ $\quad 2 /$ дм $^{3}$ & е більше 3,0 \\
\hline лізо & мг/дм ${ }^{3}$ & 0,05 \\
\hline одневий пок зник & $\mathrm{p}$ & $6,5-8,5$ \\
\hline & мг/дм ${ }^{3}$ & 0,50 \\
\hline осф ти & мг/дм ${ }^{3}$ & е норм. \\
\hline
\end{tabular}

цінк можливих мех нізмів впливу н природне середовище вн слідок перев нт жув льних опер цій н відкритому рейді $є$ в жливою ст дією н лізу з г льного екологічного ст ну р йону ерченської протоки. ет оцінки - визн чення екологічних змін, які можуть виникнути вн слідок діяльності цього морського комплексу, т оцінк зн чимості цих змін. кл днощі в ході розробки можуть з леж ти від т ких чинників: 
- $\quad$ вз ємодія (синергізм) кількох нег тивних процесів з бруднюв льних речовин бо впливів - ре кції між різними вид ми впливів ( бо між вплив ми тільки одного проекту, бо між вплив ми інших проектів у цій же сфері);

- $\quad$ вплив тр нскордонний - вплив, який чинять об'єкти господ рської т іншої діяльності однієї держ ви н екологічний ст н території іншої держ ви; для протоки цей чинник може позн читися в перенесенні з бруднюв льних речовин 3 р йону морських портових комплексів в кв торії орного й зовського морів;

- вплив екологічний - будь-як змін фізичного, природного бо культурного середовищ, спричинен ре ліз цією діяльності, з пл нов ної проектом. ід ч с вивчення морського середовищ особливу ув гу необхідно приділити змін м у просторових, якісних і кількісних х р ктеристик х біоценозів;

- $\quad$ вплив кумулятивний - вплив, що виник є вн слідок щор з більших змін бо н копичення з бруднюв льних речовин, спричинених минулими, теперішніми бо обгрунтов но передб чув ними діями, що супроводжують ре ліз цію проекту. ьому чиннику в рто приділити ув гу з огляду н велике скупчення суден протягом трив лого проміжку ч су н порівняно невеликій кв торії ерченської протоки.

од льше дослідження в цьому н прямі необхідне, одн к ускл днене з критою к тегорією використ ння зон рейдових опер цій т утрудненням доступу в цю зону контрольних служб.

особливу ув гу з слуговує той ф кт, що необхідн суч сн об'єктивн методик оцінки якості н вколишнього середовищ з погляду суч сної екології. ля створення т кої методики потрібн розробк критеріїв, згідно з якими можн викон ти н ліз різних компонентів н вколишнього природного середовищ, i морського середовищ зокрем . Г льн методик оцінки ст ну морського середовищ необхідн тому, що н явні методичні розробки визн чення збитку і впливу н н вколишне природне середовище є суто г лузевими і не д ють 3 г льної к ртини про ст н і процеси, що відбув ються в н вколишньому середовищі, т кож ч сто д ють змогу оцінити тільки прямий збиток, що не передб ч є оцінки прихов ного (непрямого впливу), тому не можн викон ти повного підр хунку еколого-економічних збитків т г р нтув ти екологічну безпеку, що вз г лі суперечить концепції ст лого розвитку.

тже, для под льшого вивчення можн виокремити т ке:

- розробку концепції т методики оцінки ст ну морського середовищ з ур хув нням екологічних особливостей водних об'єктів;

- вивчення мех нізму з бруднення морського середовищ 3 ур хув нням тр нскордонного перенесення т кумуляції з бруднюв льних речовин;

- под льший дет льний н ліз екологічної безпеки різних компонентів морегоспод рського комплексу;

- виявлення екологічних змін і порушень у морських біоценоз х, пов'яз них $з$ господ рською діяльністю у ерченській протоці; т кож визн чення 3 лежності мех нізмів впливу і ступеня порушення в морських біоценоз х.

1. ом кин . . нтропогенные и природные источники взвешенного веществ в вод х ерченского пролив / . . ом кин, . . пиридонов , . . епыженко, . епыженко // орской экол. журн. - 2008. - № 4. - . 51-59. 
2. тишов . . р нсгр ничные спекты экологической и н виг ционной безоп сности н северо-востоке ерного и зовского морей: тезисы докл д н междун родную конференцию / . . тишов, . . тишов, . . нжебейкин. - очи : терх, 2008. - . .165-168.

3. езульт ты мониторинг 3 состоянием объектов водной среды кв тории рейдовых перегрузок в условиях производственной деятельности 2006-2009 гг.
“ орской природоохр нный центр”, г . . 54 с.

4. езульт ты мониторинг з состоянием объектов воздушной среды з 2006-2009 гг. в условиях производственной деятельности $\quad$ н якорной стоянке № 471 в ерченском проливе. -45 с.

5. удько . . стойчивое р звитие и природные ресурсы прибрежной зовоерноморской зоны рым / . . удько, . . удрик, . . илявский [и др.]. иев : - кр ин , 2012.-287 с.

6. $\quad$ л й . . пр вление морским судном : [учеб. пособие] / . . рл й. л дивосток : ор. гос. ун-т им. дмир л . . евельского, 2011.-543 с.

m ття: н дійшл до ред кцї̈ 16.07.2013

доопр иьов н 29.08.2013

прийнят до друку 10.10.2013

\title{
ENVIRONMENTAL ASPECTS OF RAID TRANSSHIPMENT IN THE KERCH STRAIT
}

\author{
Inna Kudryk, Volodymyr Portnoy \\ Kerch State Marine Technological University, \\ Ordzhonikidze Str., 82, UA - 98300, Kerch, Crimea, Ukraine, \\ e-mail: inna_kudrik@mail.ru
}

This article discusses the structure and features of the raid transshipment in the Kerch Strait. Analyzing the mechanisms of environmental impact and environmental safety of port facilities on the example of external transshipment raids mooring number 450, number $471 \mathrm{KSCP}$ and transshipment complex "Taman" and mooring number 451 (port Kavkaz). The article analyzes the impact of transfer operations and maintenance of shipboard equipment on the environment. A number of factors to improve the methodology for assessing the ecological status of the marine environment were identified.

Key words: environmental safety, maritime complex, raid operations, environmental pollution. 


\section{нн удрик, л димир ортной}

ерченский госуд рственный морской технологический университет,

ул. рджоникидзе, 82, 98300, г. ерчь, рым, крин, e-mail: inna_kudrik@mail.ru

ссмотрено структуру и особенности рейдовой перегрузки в ерченском проливе. ро н лизиров но мех низмы воздействия н окруж ющую среду и экологическую безоп сность портовых комплексов н примере внешних перегрузочных рейдов, стоянки № 450, № 471

и перегрузочного комплекс “" м нский” стоянки № 451 (порт влияния перегрузочных р бот и эксплу т ции судового оборудов ния н окруж ющую среду. пределено ряд ф кторов, при помощи учет которых можно усовершенствов ть методику оценки экологического состояния морской среды.

лючевые слов : экологическ я безоп сность, морехозяйственный комплекс, рейдовые опер ции, з грязнение окруж ющей среды. 